\title{
A Review on Synthesis Silver Nano-Particles
}

\section{Kavish Rajput, Sharad Raghuvanshi, Arun Bhatt, Sumit Kumar Rai and Pavan Kumar Agrawal}

\author{
Department of Biotechnology, G.B. Pant Engineering College, \\ Ghurdauri, Pauri, Garhwal, Uttarakhand, India \\ *Corresponding author
}

\section{A B S T R A C T}

\begin{tabular}{|l|}
\hline Key w or d s \\
Nanoparticle, \\
Synthesis, Silver \\
nanoparticle, \\
Mechanism. \\
\hline Article Info \\
\hline $\begin{array}{l}\text { Accepted: } \\
\text { 19 June 2017 } \\
\text { Available Online: } \\
\text { 10 July 2017 }\end{array}$ \\
\hline
\end{tabular}

Nanotechnology could be a very important field of modern research dealing with design, synthesis, and manipulation of particle structures ranging from approximately $1-100 \mathrm{~nm}$. Silver nanoparticles are the topics of researchers because of their distinctive properties (e.g., size and shape depending optical, antimicrobial, and electrical properties). A variety of preparation techniques have been reported for the synthesis of nanoparticles such as physical, chemical and biological synthetic methods. Nowadays, there is a growing need to develop clean, reliable and environment friendly processes, that they do not use toxic chemicals within the synthesis protocols. Green synthesis approaches include mixed-valence polyoxo metalates, polysaccharides, Tollens, biological, and irradiation method which have advantages over conventional methods involving chemical agents associated with environmental toxicity. This manuscript presents an overview of silver nanoparticle synthesis by using physical, chemical, and biological approach.

\section{Introduction}

Nanotechnology could be a quickly increasing field and has been probably utilized in a large assortment of economic product worldwide. Over the last few years, the engineering and scientific communities have been visualizing remarkable progress in the field of nanoscience and technology (Jha et al., 2014). Nanotechnology deals with small structures and materials with dimensions ranging from a few nanometers to less than 100 nanometers (Sharma and Bhargava, 2013).

The use of the term "nanotechnology" was developed to include a complete range of technologies: material sciences, where the designs of new materials for wide-ranging applications were related; to electronics, where memories, computers, components and semiconductors are related; to biotechnology, where new drug delivery and diagnostics systems are concerned (Bhatt, 2003). Some microorganisms, together with microorganism, yeast, and filament-like fungi play a crucial role within their mediation of poisonous metals through the reduction of the metal ions; thus, these microorganisms may well be used as nano-factories for nanoparticle production (Fortin and Beveridge, 2000). 
Nanoparticles are also synthesized by varying approaches along with chemical, physical and biological (Iravani et al., 2014). The chemical technique of synthesis wants short quantity of it slow for the synthesis of the giant quantity of nanoparticles, this system wants capping agents for size stabilization of the nanoparticles. Chemicals used for nanoparticles synthesis and stabilization area unit cyanogenic and lead to non-ecofriendly by-products (Chikdu et al., 2015). The need for environmental non-toxic artificial protocols for nanoparticles synthesis finally ends up within the developing interest in biological approaches that are free from the employment of cyanogenic chemicals as byproducts. Thus, there is an associate increasing demand for "green nanotechnology".

Many studies have shown that metal nanoparticles, like gold, silver, gold-silver alloy, selenium, tellurium, platinum, palladium, silica, titanium, zirconium, quantum dots and iron ore is biosynthesized by various microorganism such as actinomycetes, fungi and viruses. Endophytes comprise of a very numerous cluster of microorganisms that are present in plants and maintain a well and unassertive union with their hosts for a minimum of an amount of their life cycle (Kusari et al., 2012). Fusarium spp. is filament-like fungi that are cosmopolitan in soil, water, subterranean and aerial plant elements, plant rubbish and different organic substrates (Nelson et al., 1994).

Nanotechnology is rapidly gaining importance in a number of areas such as health care, environmental health, biomedical sciences, chemical industries, drug-gene delivery, catalysis applications (Bindhani and Panigrahi, 2014). An increasingly common application is the use of silver nanoparticles for antimicrobial coatings, medical textiles, wound dressings, and biomedical devices now contain silver nanoparticles that continuously release a low level of silver ions to provide protection against pathogenic bacteria.

The size, shape, and surface morphology of NP's play an important role in dominant their physical, chemical, optical, and electronic properties. The NP's that attract the eye of most researchers are made from bulk silver and gold (Gade et al., 2008). Nanoparticles can be engineered for shape, chemical nature, size, surface properties, surface modification to transmit special functionalities such as improved strength, catalytic properties and enhanced electrical and thermal conductivity. Different features of the engineered nanoparticles were shown in figure 1 .

\section{Various methods for nanoparticle synthesis}

Silver nanoparticles are often synthesized by varying approaches. For example, silver ions can be reduced by chemical (Sun et al., 2002), electro-chemical (Yin et al., 2003), Langmuir-Blodgett (Zhang et al., 2006; Swami et al., 2004), phytochemical methods (Callegari et al., 2003), radiation (Dimitrijevic et al., 2001) and biological techniques (Naik et al., 2002). Plant extract plays an important role in the synthesis of nanoparticles as reducing agents and stabilizing agents (Kumar et al., 2009). Silver has long been known to exhibit a strong toxicity to a wide range of micro-organisms (Liau et al., 1997) for these reasons silverbased compounds have been used extensively in many bactericidal applications (Gupta et al., 1998; Nomiya et al., 2004). Silver nanoparticles can be synthesized by various types of methods (Figure 2).

\section{Chemical approach for synthesis of silver nanoparticles}

The production of nanoparticles majorly involves physical and chemical processes. Silver nanomaterials could also be obtained 
by every the alleged 'top-down' and 'bottomup' ways that. The top-down technique involves the mechanical grinding of bulk metals and resultant stabilization of the following nanosized metal particles by the addition of mixture protecting agents (Gaffet et al., 1996; Amulyavichus et al., 1998). The bottom-up ways that on the alternative hand embraces reduction of metals, natural science ways and sonodecomposition. A microwave synthesis of silver nanoparticles involves the reduction of silver nanoparticles by variable frequency microwave radiation as against the normal heating technique. The plan of action yields a faster reaction and offers an improved concentration of silver nanoparticles with identical temperature and exposure.

The most common approach for the synthesis of silver nanoparticles is a chemical reduction by organic and inorganic reducing agents. In general, completely different reducing agents like sodium citrate, ascorbate, sodium borohydride $\left(\mathrm{NaBH}_{4}\right)$, elemental hydrogen, polyol method, Tollens chemical agent, N, Ndimethylformamide (DMF) and poly-ethylene glycol block copolymers are used for reduction of silver ions $\left(\mathrm{Ag}^{+}\right)$in liquid or nonaqueous solutions. The same reducing agents cut back silver ions $\left(\mathrm{Ag}^{+}\right)$and result in the formation of metallic silver $\left(\mathrm{Ag}^{0}\right)$, which is followed by agglomeration into oligomeric clusters. These clusters eventually result in the formation of metallic mixture silver particles (Wiley et al., 2005; Merga et al., 2007; Evanoff, 2004). It's necessary to use protecting agents to stabilize dispersive nanoparticles throughout the course of metal nanoparticle preparation and shield the nanoparticles that may be absorbed on or bind into nanoparticle surfaces, avoiding their agglomeration (Oliveira et al., 2005). The presence of surfactants comprising functionalities (e.g., thiols, amines, acids, and alcohols) for interactions with particle surfaces will stabilize particle growth, and shield particles from the geological phenomenon, agglomeration, or losing their surface properties.

Recently, an easy one-step method, Tollens technique, has been used for the synthesis of silver nanoparticles with a controlled size (Iravani et al., 2014). Within the changed Tollens procedure, silver ions are reduced by saccharides within the presence of ammonia, yielding silver nanoparticle films (50-200 $\mathrm{nm})$, silver hydrosols $(20-50 \mathrm{~nm})$ and silver nanoparticles of various shapes (Yin et al., 2002).

\section{Physical approaches for synthesis of silver nanoparticles}

Most important physical approaches embrace evaporation-condensation and optical device ablation. Varied metal nanoparticles like silver, gold, lead sulphide, sulfide, and carbon have been synthesized victimization by the evaporation-condensation methodology. The absence of solvent contamination within the ready skinny films and also the uniformity of nanoparticles distribution square measure the benefits of physical approaches as compared with chemical processes (Kruis and Rellinghaus, 2000; Magnusson et al., 1999). It absolutely was incontestable that silver nanoparticles may be synthesized via a tiny, low ceramic heater with a neighbourhood heating supply (Jung et al., 2006).

The gaseous vapour will cool at an appropriate speed rate, as a result of the gradient within the neighbourhood of the heater surface is incredibly steep as compared therewith of a tube chamber. This makes attainable the formation of tiny nanoparticles in high concentration. This physical methodology is helpful as a nanoparticle generator for long-run experiments for inhalation toxicity studies, and as an activity device for nanoparticle measure instrumentality (Jung et al., 2006). 
Silver nanoparticles may be synthesized by optical device ablation of tiny bulk materials in solution (Mafune et al., 2001; Mafune et al., 2000; Kabashin, 2003; Dolgaev et al., 2002; Sylvestre et al., 2004). The ablation potency and also the characteristics of creating nanosilver particles rely upon several factors like the wavelength of the optical device contact the tinny target, the length of the optical device pulses (in the femto-, picoand unit of time regime), the laser fluence, the ablation time length and also the effective liquid medium, with or while not the presence of surfactants (Kim et al., 2005; Link et al., 2000; Kawasaki, 2006; Tarasenko et al., 2006). One vital advantage of the optical device ablation technique compared to alternative strategies for production of metal colloids is that the absence of chemical reagents in solutions. Therefore, pure and uncontaminated metal colloids for more applications are ready by this method (Tsuji et al., 2002).

\section{Biological synthesis of silver nanoparticles}

Although chemical and physical methods are considered to be successful methods to produce well-defined nanoparticles, but they have certain limitations like an increase in the cost of production, the release of hazardous by-products, long time for synthesis and difficulty in purification (Nagajyothi and Lee, 2011).

It's degree inevitable proven fact that the silver nanoparticles synthesized need to be handled by humans and may be procurable at cheaper rates for his or her effective utilization; therefore, there is a need for degree environmentally and economically potential due to synthesize these nanoparticles. The growing needs to be compelled to develop environmentally friendly and economically potential technologies for material synthesis junction rectifier to the design for biomimetic ways in which of synthesis (Kalishwaralal et al., 2008).

Ahmed et al., (2016) reported three major sources of synthesizing silver nanoparticles: bacteria, fungi, and plant extracts (Table 1). The three major elements involved in the preparation of nanoparticles by biological ways in which are the solvent medium for synthesis, the environmentally friendly reducer, and a nontoxic useful agent (Iravani et al., 2014).

However, the natural event of infectious diseases caused by antibiotic-resistant infective microorganism has brought the main focus back on the silver and its mixture forms. At present, clothing, nine respirators, family water filters, contraceptives, antibacterial sprays, cosmetics, detergent, dietary supplements, cell phones, laptop computer keyboards, and children's toys are among the merchandise being marketed that supposedly exploit the antimicrobial properties of silver nanomaterials (Mirjalili et al., 2013).

\section{Nanoparticles synthesized from bacteria}

Inorganic nanoparticles like silver, gold, silicon oxide, magnesium, cadmium sulphide can be synthesized by many organisms. The resistance for silver ions caused by the bacterial cell in their environment is responsible for nanoparticles synthesis (Saklani et al., 2012).

The primary proof of microorganism synthesizing silver nanoparticles was established by the bacterium bacteria genus Pseudomonas stutzeri AG259 strain that was isolated from mine (Haefeli et al., 1984). The important and widely accepted mechanism of silver biogenesis is that the presence of the enzyme nitrate reductase (Kumar et al., 2007). The accelerator converts nitrate into 
nitrite. In in vitro synthesis of silver by microorganisms, the presence of alphanicotinamide purine dinucleotide phosphate reduced kind (NADPH)-dependent nitrate protein would remove the downstream method step that is required in different cases (Prabhu and Poulose, 2012).

Throughout the reduction, nitrate is regenerate into cluster and conjointly the lepton is transferred to the silver ion; hence, the silver particle is reduced to silver $\left(\mathrm{Ag}^{+}\right.$to $\left.\mathrm{Ag}^{0}\right)$. Various bacteria is used for synthesis of silver nanoparticles are Pseudomonas stutzeri (Klaus et al., 1999), Bacillus megaterium (Fu et al., 1999), Plectonema boryanum (Lengke et al., 2007), Enterobactor cloacae (Minaeian et al., 2008), Escherichia coli (El-Shanshoury et al., 2011), Bacillus licheniformis (Kalimuthu et al., 2008), Lactobacillus fermentum (Sintubin et al., 2009), Klebsiella pneumonia (Mokhtari et al., 2009), Proteus mirabilis (Samadi et al., 2009), Brevibacterium casei (Kalishwaralal et al., 2010).

\section{Nanoparticles synthesized from fungi}

If a comparison of fungi is made with bacteria then, fungi can manufacture larger amounts of nanoparticles as a result of secreting large amounts of proteins that directly translate to higher productivity of nanoparticles (Mohanpuria et al., 2008).

The mechanism of silver nanoparticle production by fungi is purported to the subsequent steps: trapping of $\mathrm{Ag}^{+}$ions at the surface of the fungal cells and additionally the next reduction of the silver ions by the enzymes gift at intervals the fungal system (Mukherjee et al., 2001). The accelerators like NADPH-dependent nitrate reductase and a shuttle quinine extracellular process are a unit responsible for nanoparticle formation (Ahmad et al., 2003). A significant disadvantage of the microbes to synthesize silver nanoparticles is that it is an extremely slow technique once compared with plant extracts (Tashi et al., 2016).

Hence, the employment of plant extracts to synthesize silver nanoparticles becomes associate chance that is potential. Various fungi used for the synthesis of silver nanoparticles are Verticillium sp. (Mukherjee et al., 2001), Phoma sp. 3.2883 (Chen et al., 2003), Fusarium oxysporum (Duran et al., 2005), Phanerochaete chrysosporium (Vigneshwaran et al., 2006), Aspergillus fumigates (Bhainsa et al., 2006), Aspergillus flavus (Vigneshwaran et al., 2007), Fusarium semitectum (Basavaraja et al., 2008), Coriolus versicolor (Sanghi and Verma, 2009), Fusarium solani (Gade et al., 2009), Aspergillus clavatus (Verma et al., 2010).

\section{Nanoparticles synthesized by algae}

In the plant kingdom, algae are diverse groups that are being explored for their application in nanotechnology. Hosea et al., (1986) reported the synthesis of $\mathrm{Au}$ nanoparticles on the alga Chlorella vulgaris. Lengke et al., (2006) reported the synthesis of $\mathrm{Au}$ nanoparticles having controlled shape by using the bluegreen algae Plectonema boryanum by treating them with aqueous $\mathrm{Au}\left(\mathrm{S}_{2} \mathrm{O}_{3}\right)_{3}$ and $\mathrm{AuCl}_{4}$ solutions.

Singaravelu et al., (2007) repoted the rapid formation of gold nanoparticles through extracellular biosynthesis in marine alga Sargassum wightii. Scarano and Morelli, (2003) reported the fabrication of phytochelatin coated $\mathrm{CdS}$ nano crystals by using the phyto-planktonic algae Phaeodactulum tricornatum. Konishi et al., (2007) reported the synthesis of $\mathrm{Pt}$ nanoparticles of $5 \mathrm{~nm}$ from aqueous $\mathrm{PtCl}_{6}{ }^{2-}$ at neutral $\mathrm{pH}$ under room temperature by using Shewanella algae. 
Table.1 Synthesis of different nanoparticles from biological sources

\begin{tabular}{|c|c|c|c|c|c|}
\hline Biological sources & $\begin{array}{l}\text { NP's } \\
\text { produced }\end{array}$ & NP's size & NP's shape & Applications & References \\
\hline \multicolumn{6}{|l|}{ Bacteria } \\
\hline Bacillus subtilis & $\mathrm{Ag}$ & $5-60 \mathrm{~nm}$ & Spherical and triangular & \multirow{5}{*}{$\begin{array}{l}\text { Antifungal } \\
\text { and } \\
\text { antibacterial }\end{array}$} & $\begin{array}{l}\text { Saifuddin } \text { et al., } \\
2009\end{array}$ \\
\hline $\begin{array}{l}\text { Pseudomonas } \\
\text { aeruginosa }\end{array}$ & $\mathrm{Au}$ & $15-30 \mathrm{mn}$ & Quasi-spherical & & $\begin{array}{l}\text { Husseiny et al., } \\
2007\end{array}$ \\
\hline $\begin{array}{l}\text { Rhodopseudomona } \\
\text { s capsulate }\end{array}$ & $\mathrm{Au}$ & $20-25 \mathrm{~nm}$ & Nanowires & & He et al., 2008 \\
\hline Escherichia coli & $\mathrm{Pd}$ & $20-50 \mathrm{~nm}$ & Spherical & & $\begin{array}{l}\text { Deplanche and } \\
\text { Macaskie,2008 }\end{array}$ \\
\hline K. pneumonia & $\mathrm{Ag}$ & $40 \mathrm{~nm}$ & - & & $\begin{array}{l}\text { Deplanche } \text { et al., } \\
2008\end{array}$ \\
\hline \multicolumn{6}{|l|}{ Fungi } \\
\hline $\begin{array}{l}\text { Aspergillus } \\
\text { fumigates }\end{array}$ & $\mathrm{Ag}$ & $5-25 \mathrm{~nm}$ & - & \multirow{3}{*}{ Antibacterial } & $\begin{array}{l}\text { Ratnasri and } \\
\text { Hemalatha, } 2014\end{array}$ \\
\hline $\begin{array}{l}\text { Fusarium } \\
\text { semitectum }\end{array}$ & $\mathrm{Ag}$ & $20-25 \mathrm{~nm}$ & Spherical & & $\begin{array}{l}\text { Basavaraja et al., } \\
2008\end{array}$ \\
\hline Verticillum sp. & $\mathrm{Ag}$ & $20.25 \mathrm{~nm}$ & Spherical & & $\begin{array}{l}\text { Mukherjee } \text { et al., } \\
2001\end{array}$ \\
\hline \multicolumn{6}{|l|}{ Algae } \\
\hline Diatoms & \multirow[b]{2}{*}{$\mathrm{SiO}_{2}$} & \multirow[b]{2}{*}{$50-100 \mathrm{~nm}$} & - & \multirow{2}{*}{$\begin{array}{l}\text { Antibacterial } \\
\text { and } \\
\text { antifungal }\end{array}$} & \multirow{2}{*}{$\begin{array}{l}\text { Singaravelu et al., } \\
2007\end{array}$} \\
\hline Sargassum algae & & & - & & \\
\hline \multicolumn{6}{|l|}{ Yeast } \\
\hline Yeast $M K Y 3$ & $\mathrm{Ag}$ & $2-5 \mathrm{~nm}$ & Hexagonal & \multirow{4}{*}{ Antibacterial } & Kowshik et al., 2002 \\
\hline Candida glabrata & $\mathrm{CdS}$ & $20 \mathrm{~A}^{0}$ & - & & $\begin{array}{l}\text { Haverkamp et al., } \\
2007\end{array}$ \\
\hline $\begin{array}{l}\text { Schizo } \\
\text { saccharomyces }\end{array}$ & $\mathrm{CdS}$ & $1-1.5 \mathrm{~nm}$ & Hexagonal & & Kowshik et al., 2002 \\
\hline P. jadini & $\mathrm{Au}$ & $\begin{array}{l}\text { Few } 100 \\
\mathrm{~nm}\end{array}$ & - & & $\begin{array}{l}\text { Gericke and } \\
\text { Pinches,2006 }\end{array}$ \\
\hline \multicolumn{6}{|l|}{ Plants } \\
\hline Medicago sativa & $\mathrm{Au}$ & $4-10 \mathrm{~nm}$ & $\begin{array}{l}\text { Fcc twinned, crystal, } \\
\text { icosahedral }\end{array}$ & \multirow{6}{*}{$\begin{array}{l}\text { Antibacterial } \\
\text { and } \\
\text { antifungal }\end{array}$} & Gardea et al., 2002 \\
\hline Chilopsis linearis & $\mathrm{Au}$ & $1.1 \mathrm{~nm}$ & $\begin{array}{l}\text { fcc tetrahedral, } \\
\text { decahedral, hexagonal, } \\
\text { icosahedral } \\
\text { multitwinned, irregular, } \\
\text { and rod shape }\end{array}$ & & $\begin{array}{l}\text { Armendariz et al., } \\
2004\end{array}$ \\
\hline Cupressus torulosa & $\mathrm{Ag}$ & & & & Rajput et al., 2016 \\
\hline $\begin{array}{l}\text { Pelargonium } \\
\text { graveolens }\end{array}$ & $\mathrm{Au}$ & $21-70 \mathrm{~nm}$ & $\begin{array}{l}\text { Spherical rods, flat, } \\
\text { sheets and triangular }\end{array}$ & & Shankar et al., 2003 \\
\hline Medica gosativa & $\mathrm{Ag}$ & $2-20 \mathrm{~nm}$ & Icosahedral & & Gardea et al., 2003 \\
\hline Azadirachta indica & $\mathrm{Ag}$ & $50-100 \mathrm{~nm}$ & core-shell structure & & Shankar et al., 2004 \\
\hline
\end{tabular}


Fig.1 Various features contributing to the diversity of wide variety of engineered nanoparticles
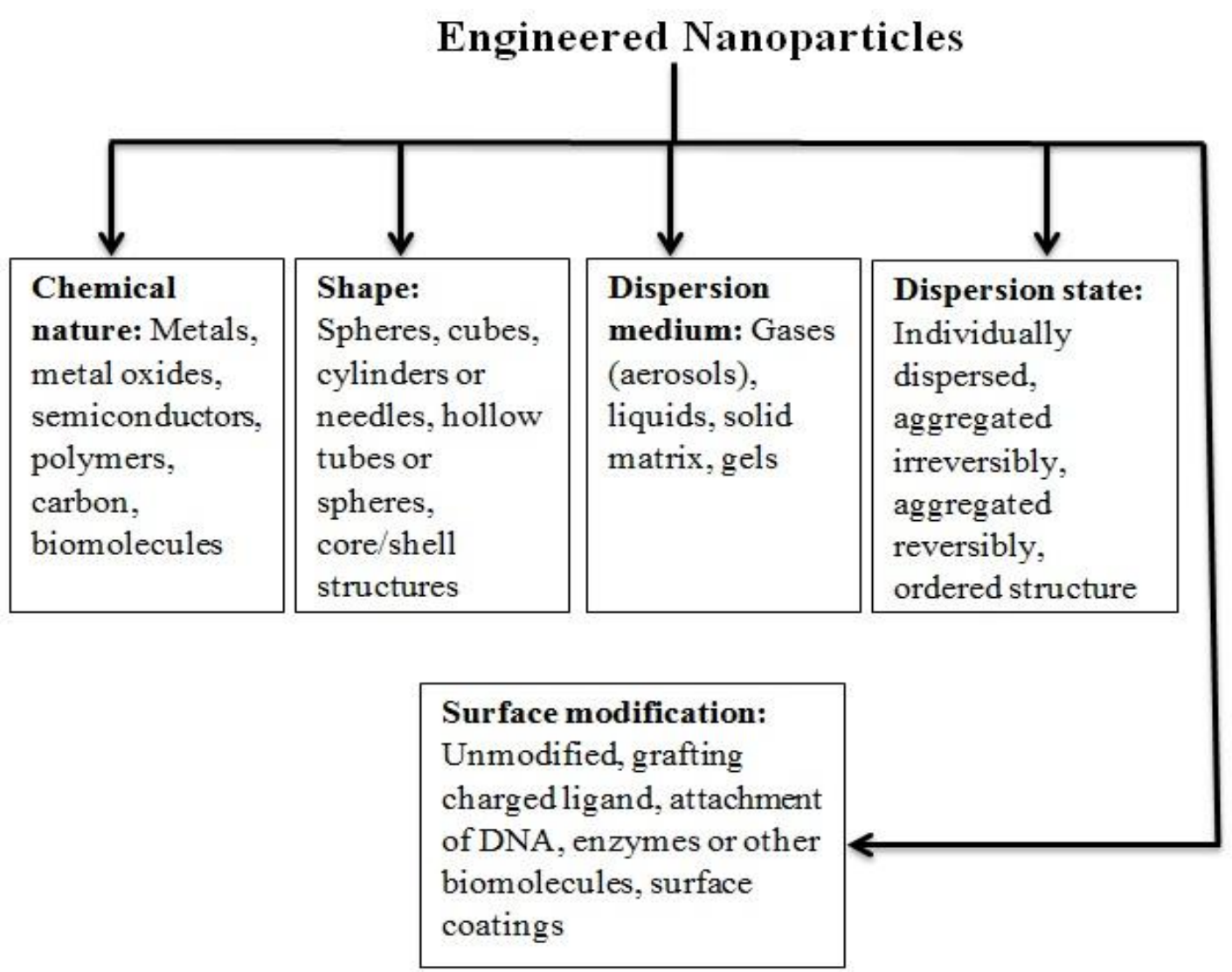

Fig.2 Different methods of silver nanoparticles synthesis

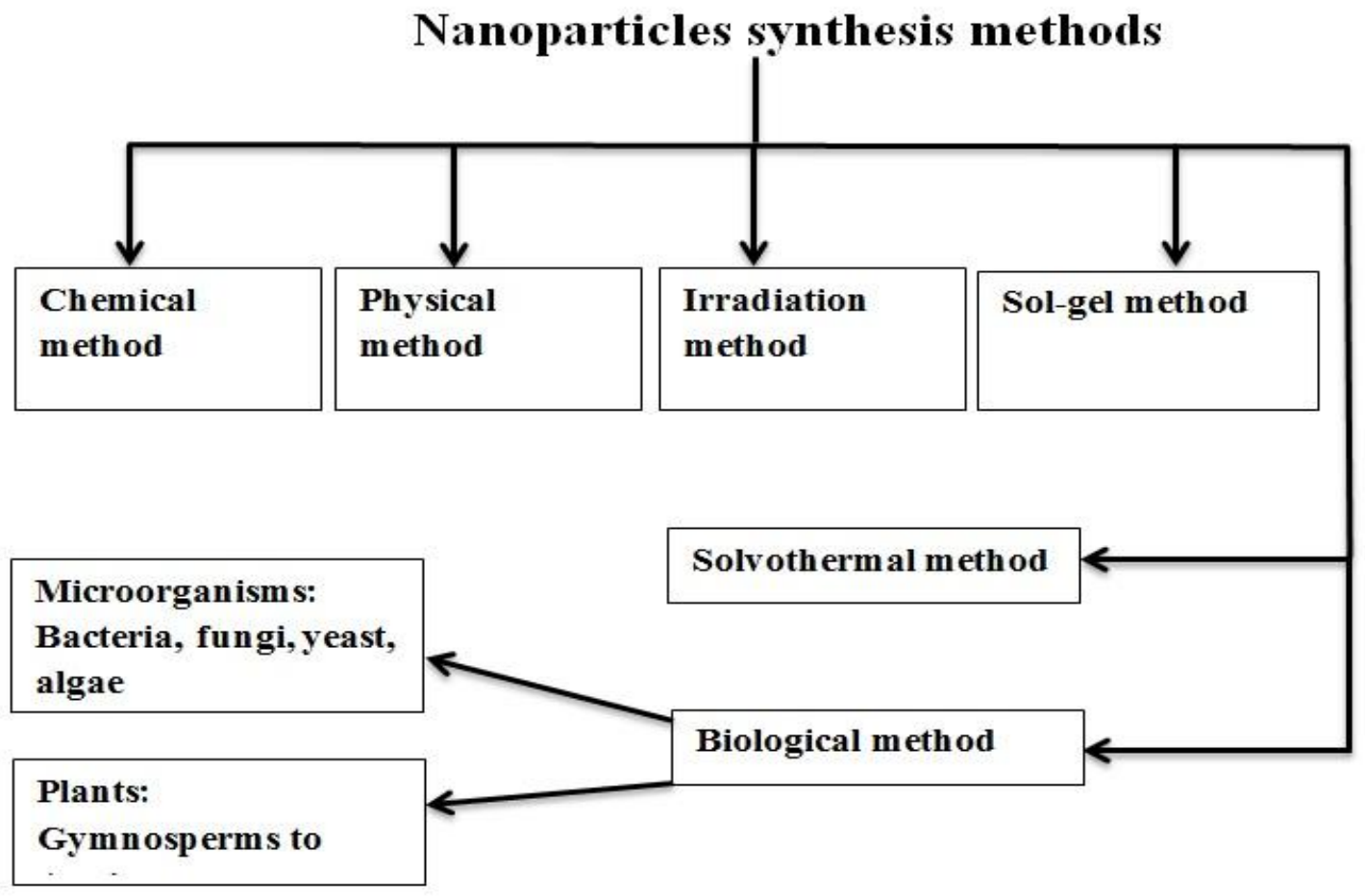


Fig.3 Proposed mechanism for silver nanoparticles synthesis using Bacillus licheniformis (adapted from Kalimuthu et al., 2008; Sadowski, 2010)

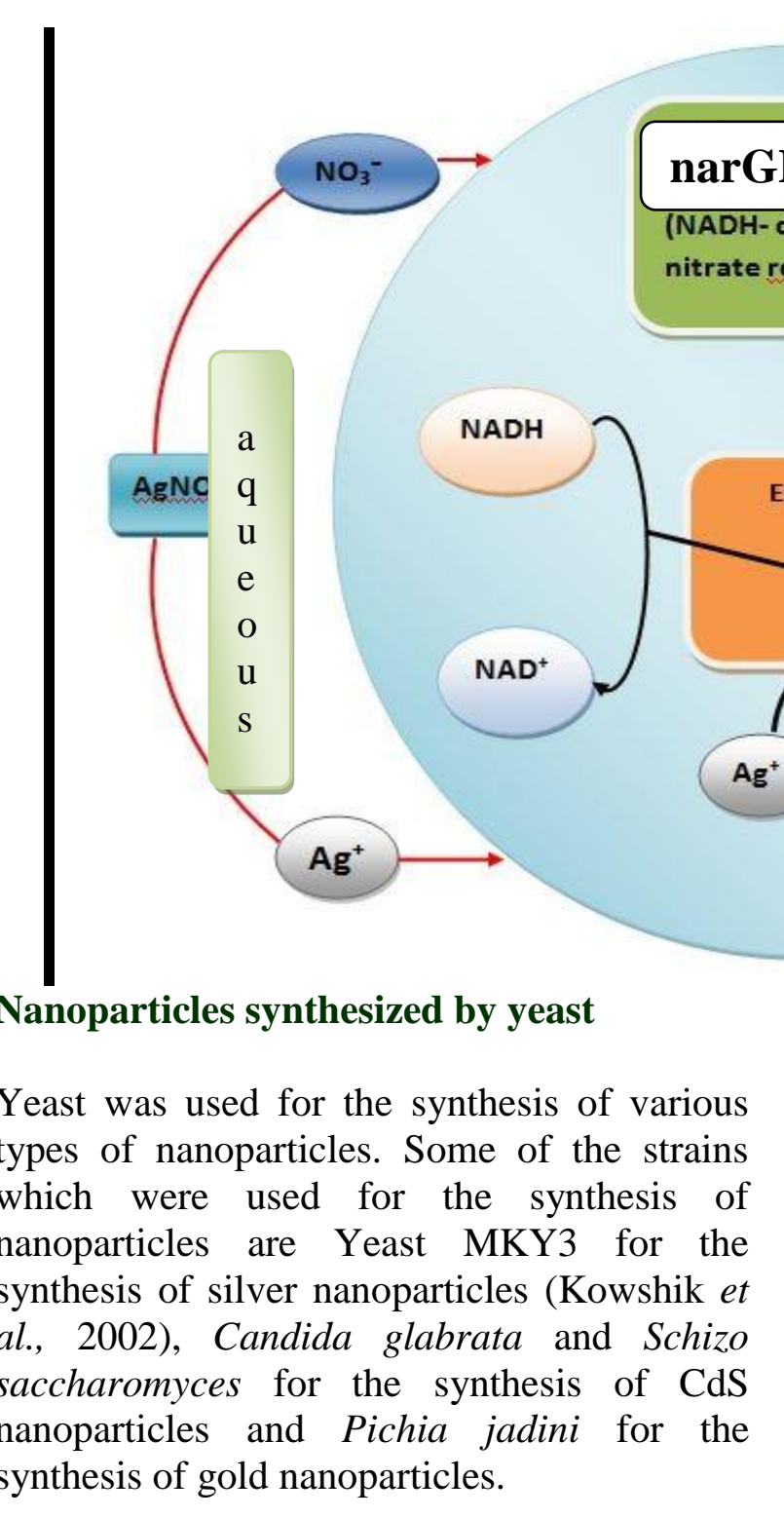

\section{Nanoparticles synthesized from plants}

The most necessary advantage of the plant extracts for silver nanoparticle synthesis is that they are merely gettable, safe, and nontoxic in most cases, have a broad quite metabolites which will aid among the reduction of silver ions, and area unit quicker than microbes among the synthesis (Prabhu and Poulose, 2012). The main mechanism used for the process is a plant-assisted

\section{Bacillus licheniformis cell}

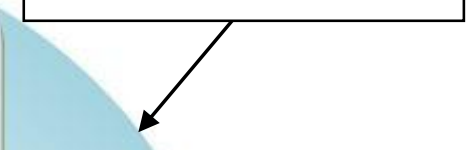


reduction of the ions. Plant extracts area unit simple and convenient various to chemical and physical strategies used for the synthesis of silver nanoparticles. Various plant extracts used for the synthesis of metallic nanoparticles such as Neem (Shankar et al., 2004), Geranium (Shankar et al., 2003), Aloe vera (Chandran et al., 2006), Cinnamomum (Huang et al., 2007), Mushroom (Philip, 2009), Mangifera indica (Philip, 2010), Mangolia kobus (Song et al., 2009), Pear fruit (Ghodake et al., 2010) and Tulsi (Philip et al., 2011).

Mechanism for the synthesis of
nanoparticles
component

A possible mechanism behind the synthesis of silver nanoparticles using bacteria Bacillus lichemiformis was investigated by Kalimuthu and coworkers (Kalimuthu et al., 2008). The enzyme which is involved in the synthesis of silver nanoparticle belongs to nitrate reductase and also present in $B$. lichemiformis. The presence of nitrate reductase enzyme is the most accepted mechanism of silver nanoparticles synthesis. The enzyme nitrate reductase reduces the silver ions to metallic silver by the electrons donated by NADH. NADH plays a very important role as a reducing agent to donate electrons (Fig. 3).

Similarly, the gold nanoparticles were prepared on the surface of bacteria cells as a result of incubation of bacteria with $\mathrm{AuCl}_{4}{ }^{-}$ ions. On incubation, the bacteria Rhodopseudomans capsulate was adapted to the $\mathrm{AuCl}_{4}$ containing growth medium and causes the bioreduction of gold ions ( $\mathrm{He}$ et al., 2007). The aqueous chloroaurate ions were reduced during the contact with the bacteria cell groups such as amino, sulfhydryl and carboxylic groups. These groups had the positive charge which depends on $\mathrm{pH}$ of the solution. The adsorption of $\mathrm{AuCl}_{4}{ }^{-}$ions on the surface of bacterial cell occurred and bioreduction of gold ions is initiated by electron transfer from NADH by NADHdependent reductase as an electron carrier. Thus, gold ions reduced to gold.

Eukaryotic microorganisms such as fungi can be used to synthesize nanoparticles of different sizes and chemical composition (Sadowski, 2010). The extracellular synthesis of silver and gold-silver nanoparticles has been observed by fungus Fusarium oxysporum biomass (Ahmad et al., 2003). The whole credit for reduction of silver ions by Fusarium oxysporum goes to the enzyme nitrate-dependent reductase and a shuttle quinine extracellular process.

The synthesis of silver particles using soil dwelled Aspergillus niger strains was investigated by Sadowski et al., (2008a, $2009 b)$. The capacity of silver nanoparticles production has been dependent on the reductase/electron shuttle relationships. The extracellular enzymes such as naphthoquinons and anthraquinones showed excellent redox properties, they can act as electron shuttle in silver ions reduction (Sahayaraj et al., 2011).

Plants are easily available, safe, and nontoxic contains a variety of metabolites that can help in the reduction of metal ions. It was reported that plants extracts contain biomolecules including polyphenols, ascorbic acid, flavonoids, sterols, triterpenes, alkaloids, alcoholic compounds, polysaccharides, saponins, $\beta$-phenylethylamines, glucose and fructose, and proteins/enzymes which could be used as reductant to react with silver ions and therefore used as scaffolds to direct the formation of AgNPs in the solution (Prasad, 2014). It was also considered that some biomolecules like glucose and ascorbate reduce $\mathrm{AgNO}_{3}$ and $\mathrm{HAuCl}_{4}$ to form nanoparticles. In neem leaf broth, terpenoids 
are the surface active molecules stabilizing the nanoparticles and reaction of the metal ions is possibly facilitated by reducing sugars (Shankar et al., 2004). The action of flavonoids resides mainly in their ability to donate electrons or hydrogen atoms. Hence, the presence of proteins, enzymes, phytochemicals within the plant extract reduces the silver salts and also provide excellent tenacity against agglomeration, which can be further studied to understand the mechanism of evolution by biological systems (Saxena et al., 2012).

In the recent years, noble nanoparticles have attracted and emerged in the field of biology, medicine and electronics due to their incredible applications. There were several methods have been used for synthesis of nanoparticles such as toxic chemicals and high energy physical procedures. To overcome these, biological techniques has been used for the synthesis of various metal nanoparticles. From the biotechnological point of view, the silver nanoparticles have wide potential applications in the biomedical field and also the procedure of biosynthesis has several advantages such as costeffectiveness, less time consuming, largescale commercial production, and compatibility for medical and pharmaceutical applications.

Moreover, the biological approach, in particular the usage of natural organisms has offered a reliable, simple, nontoxic and environmental friendly method. Hence, this article is targeted on the biological synthesis of silver nanoparticles. Silver nanoparticles show variable applications so that these can be used in medical purposes, advanced portable gadgets and also be used in the production of cloths, leather items, and coating because silver nanoparticles can protect these items from the attack of various harmful microorganisms.

\section{Acknowledgement}

We gratefully acknowledge TEQIP-II and G. B. Pant Engineering College, Pauri, Garhwal for financial support and providing instrumentation facilities.

\section{References}

Ahmad A, Mukherjee P, Senapati S, Mandal D, Khan MI, Kumar R, Sastry M (2003) Extracellular biosynthesis of silver nanoparticles using the fungus Fusarium oxysporum. Colloids Surf. B 28 (4):313-8.

Ahmed S, Ahmad M, Swami BL, Ikram S (2016) A review on plants extract mediated synthesis of silver nanoparticles for antimicrobial applications: A green expertise. J Adv Res 7(1):17-28.

Al-Samarrai A (2012) Nanoparticles as alternative to pesticides in management plant diseases. IJSRP 2(4):1-4.

Amulyavichus A, Daugvila A, Davidonis R, Sipavichus C (1998) Study of chemical composition of nanostructural materials prepared by laser cutting of metals. Fizika Met. Met. 85, 111-117

Armendariz V, Herrera I, Jose-yacaman M, Troiani H, Santiago P, Gardea-Torresdey JL (2004) Size controlled gold nanoparticle formation by Avena sativa biomass: use of plants in nanobiotechnology. J. Nanopart. Res 6 (4):377-82.

Basavaraja S, Balaji SD, Lagashetty A, Rajasab AH, Venkataraman A (2008) Extracellular biosynthesis of silver nanoparticles using the fungus Fusarium semitectum. Mater. Res. Bull 43 (5):116470.

Bhainsa CK, D'Souza FS (2006) Extracellular biosynthesis of silver nanoparticles using the fungus Aspergillus fumigatus. Colloids Surf. B Biointerfaces 47:160164.

Bhatt JSA (2003) Heralding a new futureNanotechnology. Curr. Sci. 85(2):127. 
Bindhani BK, Panigrahi AK (2014) Green synthesis and characterization of gold nanoparticles using leaf extracts of Withania somnifera (Linn.) (Ashwagandha). International Journal of Materials Science and Applications. 3(6): 279-284.

Birla SS, Tiwari VV, Gade AK, Ingle AP, Yadav AP, Rai MK (2009) Fabrication of silver nanoparticles by Phoma glomerata and its combined effect against Escherichia coli, Pseudomonas aeruginosa and Staphylococcus aureus. Letters in Applied Microbiology, 48(2), pp.173-179

Callegari A, Tonti D and Chergui M (2003) Photochemically grown silver nanoparticles with wavelength-controlled size and shape. Nano Lett, 3: 1565-1568.

P.H.C., Satyanarayana, K.G. and Wypych, F., 2009. Nanocomposites: synthesis, structure, properties and new application opportunities. Materials Research, 12(1), pp.1-39.

Chandran SP, Chaudhary M, Pasricha R, Ahmad A, Sastry M (2006) Synthesis of gold nanotriangles and silver nanoparticles using Aloe vera plant extract. 22 (2):577-83.

Chen JC, Lin ZH, Ma XX (2003) Evidence of the production of silver nanoparticles via pretreatment of Phoma sp. 3.2883 with silver nitrate. LettApplMicrobiol 37 (2):105-8.

Chikdu, D., Pal, P., Gujar, A., Deshmukh, R. and Kate, S., 2015. green synthesis and characterization of silver nanoparticles by using Aloe barbadensis and its antibacterial activity. Journal of Global Biosciences, 4(7), pp.2713-2719.

Deplanche K, Macaskie LE (2008) Biorecovery of gold by Escherichia coli and Desulfovibrio desulfuricans. Biotechnol. Bioeng 99 (5):1055-64.

Deplanche K, Woods RD, Mikheenko IP, Sockett RE, Macaskie LE (2008) Manufacture of stable palladium and gold nanoparticles on native and genetically engineered flagella scaffolds. Biotechnol. Bioeng 101 (5):873-80.
Dimitrijevic NM, Bartels DM, Jonah CD, Takahashi K and Rajh $\mathrm{T}$ (2001) Radiolytically induced formation and optical absorption spectra of colloidal silver nanoparticles in supercritical ethane. J PhysChem B, 105: 954-959.

Dolgaev SI, Simakin AV, Voronov VV, Shafeev GA and Bozon-Verduraz $F$ (2002) Nanoparticles produced by laser ablation of solids in liquid environment. Applied surface science, 186(1), pp.546551.

Duran N, Marcato PD, Alves OL, De Souza GI, Esposito E (2005) Mechanistic aspects of biosynthesis of silver nanoparticles by several Fusarium oxysporum strains. J nanobiotechnology 3(1):1.

Duran N, Marcato PD, De Souza GI, Alves OL, Esposito E (2007) Antibacterial effect of silver nanoparticles produced by fungal process on textile fabrics and their effluent treatment. J. Biomed. Nanotechnol 3 (2):203-8.

El-Shanshoury AE, ElSilk SE, Ebeid ME (2011) Extracellular biosynthesis of silver nanoparticles using Escherichia coli ATCC 8739, Bacillus subtilis ATCC 6633, and Streptococcus thermophilus ESh1 and their antimicrobial activities. ISRN Nanotechnology 2011.

Evanoff DD and Chumanov G (2004) Sizecontrolled synthesis of nanoparticles. 2 . Measurement of extinction, scattering, and absorption cross sections. The Journal of Physical Chemistry B, 108(37), pp.13957-13962.

Fortin D, Beveridge T J (2000) Mechanistic routes towards biomineral surface development. Biomineralisation: From Biology to Biotechnology and medical Application, Wiley-VCH, Verlag, Germany, $2^{\text {nd }}$ edition, pp. 7.

Fu JK, Zhnag WD, Liu YY, Lin ZY, Yao BX, Weng SZ, Zeng JL (1999) Characterization of adsorption and reduction of noble metal ions by bacteria. Chem J Chinese U 20:1454-6.

Gade AK, Bonde P, Ingle AP, Marcato PD, Duran N, Rai MK (2008) Exploitation of 
Aspergillus niger for synthesis of silver nanoparticles. J Biobased Mater Bio 2 (3):243-7.

Gade A, Ingle A, Bawaskar M, Rai M (2009) Fusarium solani: a novel biological agent for the extracellular synthesis of silver nanoparticles. Journal of Nanoparticle Research 11, 2079-2085.

Gaffet E, Tachikart M, El Kedim O, Rahouadj $R$ (1996) Nanostructural materials formation by mechanical alloying: morphologic analysis based on transmission and scanning electron microscopic observations. Mater. Charact 36, $185-190$

Gardea-Torresdey JL, Gomez E, Peralta-Videa JR, Parsons JG, Troiani H, Jose-Yacaman M (2003) Alfalfa sprouts: a natural source for the synthesis of silver nanoparticles. Langmuir. 19 (4):1357-61.

Gardea-Torresdey JL, Parsons JG, Gomez E, Peralta-Videa J, Troiani HE, Santiago P, Yacaman MJ (2002) Formation and growth of $\mathrm{Au}$ nanoparticles inside live alfalfa plants. Nano Lett 2 (4):397-401.

Gericke M, Pinches A (2006) Microbial production of gold nanoparticles. Gold Bull 39 (1):22-8.

Ghodake GS, Deshpande NG, Lee YP, Jin ES (2010) Pear fruit extract-assisted roomtemperature biosynthesis of gold nanoplates. Colloids Surf. B 75 (2):584-9.

Gupta A and Silver S (1998) Molecular Genetics: Silver as a biocide: Will resistance become a problem. Nature Biotechnology, 16: 888.

Haefeli C, Franklin C, Hardy K (1984) Plasmiddetermined silver resistance in Pseudomonas stutzeri isolated from silver mine. J. Bacteriol. 158:389-392.

Haverkamp RG, Marshall AT, van Agterveld D (2007) Pick your carats: nanoparticles of gold-silver-copper alloy produced in vivo. J. Nanopart. Res 9 (4):697-700.

He S, Zhang Y, Guo Z, Gu N (2008) Biological synthesis of gold nanowires using extract of Rhodopseudomonas capsulata. BiotechnolProg 24 (2):476-80.
Hosea M, Greene B, Mcpherson R, Henzl M, Alexander MD, Darnall DW (1986) Accumulation of elemental gold on the alga Chlorella vulgaris. Inorg. Chim. Acta 123 (3):161-5.

Huang J, Li Q, Sun D, Lu Y, Su Y, Yang X, Wang H, Wang Y, Shao W, He N, Hong J (2007) Biosynthesis of silver and gold nanoparticles by novel sundried Cinnamomum camphora leaf. Nanotechnology 18 (10):105104.

Husseiny MI, El-Aziz MA, Badr Y, Mahmoud MA (2007) Biosynthesis of gold nanoparticles using Pseudomonas aeruginosa. Spectrochim. Acta Mol. Biomol. Spectrosc 67 (3):1003-6.

Iravani S, Korbekandi H, Mirmohammadi SV, Zolfaghari B (2014) Synthesis of silver nanoparticles: chemical, physical and biological methods. Res Pharm Sci., 9(6):385-406.

Jha AK, Prasad K, Prasad K, Kulkarni AR (2009) Plant system: nature's nanofactory. Colloids Surf. B 73 (2):219-23.

Jha RK, Jha PK, Chaudhary K, Rana SVS, Guha SK (2014) An emerging interface between life science and nanotechnology: present status and prospects of reproductive healthcare aided by nanobiotechnology. Nano Reviews 5:22762.

Jung JH, Oh HC, Noh HS, Ji JH and Kim SS (2006) Metal nanoparticle generation using a small ceramic heater with a local heating area. Journal of aerosol science, 37(12), pp.1662-1670

Kabashin AV and Meunier M (2003) Synthesis of colloidal nanoparticles during femtosecond laser ablation of gold in water. Journal of Applied Physics, 94(12), pp.7941-7943.

Kalimuthu K, Babu RS, Venkataraman D, Bilal M, Gurunathan S (2008) Biosynthesis of silver nanocrystals by Bacillus licheniformis. Colloids Surf. B 65 (1):150-3.

Kalishwaralal K, Deepak V, Pandian SR, Kottaisamy M, BarathManiKanth S, Kartikeyan B, Gurunathan S (2010) Biosynthesis of silver and gold 
nanoparticles using Brevibacterium casei. Colloids Surf. B 77 (2):257-62.

Kalishwaralal K, Deepak V, Ramkumarpandian S, Nellaiah H, Sangiliyandi G (2008) Extracellular biosynthesis of silver nanoparticles by the culture supernatant of Bacillus licheniformis. Mater. Lett 62 (29):4411-3.

Kawasaki M and Nishimura N (2006) 1064-nm laser fragmentation of thin $\mathrm{Au}$ and $\mathrm{Ag}$ flakes in acetone for highly productive pathway to stable metal nanoparticles. Applied Surface Science, 253(4), pp.2208-2216.

Kim S, Yoo BK, Chun K, Kang W, Choo J, Gong MS and Joo SW (2005) Catalytic effect of laser ablated Ni nanoparticles in the oxidative addition reaction for a coupling reagent of benzylchloride and bromoacetonitrile. Journal of Molecular Catalysis A: Chemical, 226(2), pp.231234.

Klaus T, Joerger R, Olsson E, Granqvist CG (1999) Silver-based crystalline nanoparticles, microbially fabricated. Proc. Natl. Acad. Sci. U.S.A 96 (24):13611-4.

Konishi Y, Ohno K, Saitoh N, Nomura T, Nagamine S, Hishida $\mathrm{H}$, Takahashi $\mathrm{Y}$, Uruga $T$ (2007) Bioreductive deposition of platinum nanoparticles on the bacterium Shewanella algae. J. Biotechno 128 (3):648-53.

Kowshik M, Ashtaputre S, Kharrazi S, Vogel W, Urban J, Kulkarni SK, Paknikar KM (2002) Extracellular synthesis of silver nanoparticles by a silver-tolerant yeast strain MKY3. Nanotechnology 14 (1):95.

Kowshik M, Deshmukh N, Vogel W, Urban J, Kulkarni SK, Paknikar KM (2002) Microbial synthesis of semiconductor $\mathrm{CdS}$ nanoparticles, their characterization, and their use in the fabrication of an ideal diode. Biotechnol. Bioeng78(5):583-8.

Kruis FE, Fissan H and Rellinghaus B (2000) Sintering and evaporation characteristics of gas-phase synthesis of size-selected $\mathrm{PbS}$ nanoparticles. Materials Science and Engineering: B, 69, pp.329-334.
Kumar AS, Abyaneh MK, Gosavi SW, Ahmad A, Khan MI (2007) Nitrate reductase mediated synthesis of silver nanoparticles from $\mathrm{AgNO}_{3}$. BiotechnolLett 29:439-445.

Kumar V and Yadav SK (2009) Plant-mediated synthesis of silver and gold nanoparticles and their applications. Journal of Chemical Technology and Biotechnology, 84(2) 151-57.

Kumar A, Vemula PK, Ajayan PM, John G (2008) Silver-nanoparticle-embedded antimicrobial paints based on vegetable oil. Nature materials, 7(3), pp.236-241.

Kusari S, Hertweck C, Spiteller M (2012) Chemical ecology of endophytic fungi: origins of secondary metabolites. Chem. Biol 19 (7):792-8.

Lengke MF, Fleet ME, Southam G (2006) Morphology of gold nanoparticles synthesized by filamentous cyanobacteria from gold (I)-thiosulfate and gold (III)chloride complexes. Langmuir 22 (6):2780-7.

Lengke MF, Fleet ME, Southam G (2007) Biosynthesis of silver nanoparticles by filamentous cyanobacteria from a silver (I) nitrate complex. Langmuir 23 (5):2694-9.

Liau SY, Read DC, Pugh WJ, Furr JR, and Russell AD (1997) Interaction of silver nitrate with readily identifiable groups: relationship to the antibacterial action ofsilver ions. Letters in Applied Microbiology, 25: 279.

Link S, Burda C, Nikoobakht B and El-Sayed MA (2000) Laser-induced shape changes of colloidal gold nanorods using femtosecond and nanosecond laser pulses. The Journal of Physical Chemistry B, 104(26), pp.6152-6163.

Mafuné F, Kohno JY, Takeda Y, Kondow T and Sawabe H (2000) Structure and stability of silver nanoparticles in aqueous solution produced by laser ablation. The Journal of Physical Chemistry B, 104(35), pp.8333-8337.

Mafuné F, Kohno JY, Takeda Y, Kondow T and Sawabe H (2001) Formation of gold nanoparticles by laser ablation in aqueous 
solution of surfactant. The Journal of Physical Chemistry B, 105(22), pp.51145120.

Magnusson MH, Deppert K, Malm JO, Bovin JO and Samuelson L (1999) Gold nanoparticles: production, reshaping, and thermal charging. Journal of Nanoparticle Research, 1(2), pp.243-251.

Merga G, Wilson R, Lynn G, Milosavljevic BH and Meisel D (2007) Redox catalysis on "naked" silver nanoparticles. The Journal of Physical Chemistry C, 111(33), pp.12220-12226.

Minaeian S, Shahverdi AR, Nohi AS, Shahverdi HR (2008) Extracellular biosynthesis of silver nanoparticles by some bacteria. J. Sci. IAU 17 (66):1-4.

Mirjalili M, Yaghmaei N, Mirjalili M (2013) Antibacterial properties of nano silver finish cellulose fabric. J Nanostruct Chem 3(1):1-5.

Mohanpuria P, Rana KN, Yadav SK (2008) Biosynthesis of nanoparticles: technological concepts and future applications. J. Nanopart 10:507-517.

Mokhtari N, Daneshpajouh S, Seyedbagheri S, Atashdehghan R, Abdi K, Sarkar S, Minaian S, Shahverdi HR, Shahverdi AR (2009) Biological synthesis of very small silver nanoparticles by culture supernatant of Klebsiella pneumoniae: the effects of visible-light irradiation and the liquid mixing process. Mater. Res. Bull 44:1415-1421.

Mukherjee P, Ahmad A, Mandal D, Senapati S, Sainkar SR, Khan MI, Parishcha R, Ajaykumar PV, Alam M, Kumar R, Sastry M (2001) Fungus-mediated synthesis of silver nanoparticles and their immobilization in the mycelial matrix: a novel biological approach to nanoparticle synthesis. Nano Lett 1 (10):515-9.

Mukherjee P, Ahmad A, Mandal D, Senapati S, Sainkar SR, Khan MI, Ramani R, Parischa R, Ajayakumar PV, Alam M, Sastry M, Kumar R (2001) Bioreduction of $\mathrm{AuCl}_{4}{ }^{-}$ions by the fungus, Verticillium $s p$. and surface trapping of the gold nanoparticles formed. Angew. Chem. Int 40:3585-3588.

Nagajyothi PC, Lee KD. (2011) Synthesis of plant-mediated silver nanoparticles using Dioscoreabatatas rhizome extract and evaluation of their antimicrobial activities. Journal of nanomaterials 2011:49.

Naik RR, Stringer SJ, Agarwal G, Jones S and Stone MO (2002) Biomimetic synthesis and patterning of silver nanoparticles. Nat. Mater, 1(3): 169-72.

Nelson PE, Dignani MC, Anaissie EJ (1994) Taxonomy, biology, and clinical aspects of Fusarium species. Clin. Microbiol. Rev 7 (4):479-504.

Nomiya K, Yoshizawa A, Tsukagoshi K, Kasuga NC, Hirakawa S and Watanabe J (2004) Synthesis and structural characterization of silver (I), aluminium (III) and cobalt(II) complexes with 4isopropyltropolone (hinokitiol)showing noteworthy biological activities. Action of silver (I)- oxygen bonding complexes on the antimicrobial activities. Journal of Inorganic Biochemistry, 98: 46.

Oliveira MM, Ugarte D, Zanchet D and Zarbin AJ (2005) Influence of synthetic parameters on the size, structure, and stability of dodecanethiol-stabilized silver nanoparticles. Journal of colloid and interface science, 292(2), pp.429-435.

Philip D (2009) Biosynthesis of $\mathrm{Au}, \mathrm{Ag}$ and $\mathrm{Au}-\mathrm{Ag}$ nanoparticles using edible mushroom extract. Spectrochim. Acta Mol. Biomol 73 (2):374-81.

Philip D (2010) Rapid green synthesis of spherical gold nanoparticles using Mangifera indica leaf. Spectrochim. Acta Mol. Biomol. Spectrosc 77 (4):807-10.

Philip D, Unni C (2011) Extracellular biosynthesis of gold and silver nanoparticles using Krishna tulsi (Ocimum sanctum) leaf. Physica E: Lowdimensional Systems and J Nanostruct 43 (7):1318-22.

Prabhu S, Poulose EK (2012) Silver nanoparticles: mechanism of antimicrobial action, synthesis, medical 
applications, and toxicity effects. Int Nano Lett 2:32.

Prasad, R (2014) Synthesis of silver nanoparticles in photosynthetic plants. Journal of Nanoparticles, 2014.

Rajput K, Bhatt A and Agrawal PK (2016) Plant mediated biosynthesis, characterization and application of silver nanoparticles by leaves extract of Cupressus torulosa. International Journal of Advanced Research, Volume 4, Issue 7, 1199-1207

Ratnasri PV and Hemalatha KPJ (2014) Biological Synthesis of Silver Nanoparticles from Aspergillus fumigatus. American Journal of Advanced Drug Delivery, 2(6), pp.741-751.

Sadowski, Z.; Maliszewska, H.I.; Grochowalska, B.; Polowczyk, I.; Kozlecki, T. (2008 B). Synthesis of silver nanoparticles using microorganisms, Materials Science-Poland, 26, 2, 419-424

Sadowski Z, Maliszewska I, Polowczyk I, Kozlecki T, Grochowalska B (2008 A) Biosynthesis of colloidal-silver particles using microorganisms, Polish J. Chem., $82,377-382$

Sadowski Z (2010) Biosynthesis and Application of Silver and Gold Nanoparticles, Silver Nanoparticles, David Pozo Perez (Ed.), InTech, DOI: 10.5772/8508.

Sahayaraj K, Rajesh S (2011) Bionanoparticles: synthesis and antimicrobial applications. Science against microbial pathogens: communicating current research and technological advances, 228-244.

Saifuddin N, Wong CW, Yasumira AA (2009) Rapid biosynthesis of silver nanoparticles using culture supernatant of bacteria with microwave irradiation. J. Chem6 (1):6170.

Saklani V, Suman, Jain VK (2012) Microbial synthesis of silver Nanoparticles: A Review, J Biotechnol Biomaterial S13:007.

Samadi N, Golkaran D, Eslamifar A, Jamalifar H, Fazeli MR, Mohseni FA (2009) Intra/Extracellular Biosynthesis of Silver
Nanoparticles by an Autochthonous Strain of Proteus mirabilis Isolated from Photographic Waste. J. Biomed. Nanotechnol 5 (3):247-53.

Sanghi R, Verma P (2009) Biomimetic synthesis and characterisation of protein capped silver nanoparticles. BIORESOURCE TECHNOL 100 (1):501-4.

Saxena A, Tripathi RM, Zafar F, Singh P, (2012) Green synthesis of silver nanoparticles using aqueous solution of Ficus benghalensis leaf extract and characterization of their antibacterial activity. Materials Letters, 67(1), 91-94.

Scarano G, Morelli E (2003) Properties of phytochelatin-coated CdS nanocrystallites formed in a marine phytoplanktonic alga (Phaeodactylum tricornutum, Bohlin) in response to Cd. Plant Sci 165 (4):803-10.

Shankar SS, Ahmad A, Pasricha R, Sastry M (2003) Bioreduction of chloroaurate ions by geranium leaves and its endophytic fungus yields gold nanoparticles of different shapes. J. Mater. Chem 13 (7):1822-6.

Shankar SS, Rai A, Ahmad A, Sastry M (2004) Rapid synthesis of $\mathrm{Au}, \mathrm{Ag}$, and bimetallic $\mathrm{Au}$ core-Ag shell nanoparticles using Neem (Azadirachta indica) leaf broth. J. Colloid Interface Sci275 (2):496-502.

Sharma P, Bhargava M (2013) Applications and characteristics of nanomaterials in industrial environment. IJCSEIERD 3(4):63-72.

Singaravelu G, Arockiamary JS, Kumar VG, Govindaraju K (2007) A novel extracellular synthesis of monodisperse gold nanoparticles using marine alga, Sargassum wightii Greville. Colloids Surf. B 57(1):97-101.

Sintubin L, De Windt W, Dick J, Mast J, van der Ha D, Verstraete W, Boon N (2009) Lactic acid bacteria as reducing and capping agent for the fast and efficient production of silver nanoparticles. ApplMicrobiolBiotechnol 84 (4):741-9.

Song JY, Kim BS (2009) Rapid biological synthesis of silver nanoparticles using 
plant leaf extracts. Bioprocess BiosystEng32 (1):79-84.

Sun, Y. and Xia, Y., 2002. Shape-controlled synthesis of gold and silver nanoparticles. Science, 298(5601), pp.2176-2179.

Swami A, Selvakannan PR, Pasricha R and Sastry M (2004) One-step synthesis of ordered two dimensional assemblies of silver nanoparticles by the spontaneous reduction of silver ions by pentadecylphenol Langmuir monolayers. J PhysChem B, 108: 19269-19275.

Sylvestre JP, Kabashin AV, Sacher E, Meunier M and Luong JH (2004) Stabilization and size control of gold nanoparticles during laser ablation in aqueous cyclodextrins. Journal of the American Chemical Society, 126(23), pp.7176-7177.

Tarasenko NV, Butsen AV, Nevar EA and Savastenko NA (2006) Synthesis of nanosized particles during laser ablation of gold in water. Applied surface science, 252(13), pp.4439-4444.

Tashi T, Gupta NV, Mbuya VB (2016) Silver nanoparticles: Synthesis, mechanism of antimicrobial action, characterization, medical applications, and toxicity effect. J. Chem. Pharm. Res 8(2):526-537.

Tsuji $\mathrm{T}$, Iryo $\mathrm{K}$, Watanabe $\mathrm{N}$ and Tsuji $\mathrm{M}$ (2002) Preparation of silver nanoparticles by laser ablation in solution: influence of laser wavelength on particle size. Applied Surface Science, 202(1), pp.80-85.
Verma VC, Kharwar RN, Gange AC (2010) Biosynthesis of antimicrobial silver nanoparticles by the endophytic fungus Aspergillus clavatus. Nanomedicine 5 (1):33-40.

Vigneshwaran N, Ashtaputre NM, Varadarajan PV, Nachane RP, Paralikar KM, Balasubramanya RH (2007) Biological synthesis of silver nanoparticles using the fungus Aspergillus flavus. Mater. Lett 66:1413-1418.

Vigneshwaran N, Kathe AA, Varadarajan PV, Nachane RP, Balasubramanya RH (2006) Biomimetics of silver nanoparticles by white rot fungus. Phaenerochaete chrysosporium. Colloids Surf. B 53 (1):55-9.

Wiley B, Sun Y, Mayers B and Xia Y (2005) Shape- controlled synthesis of metal nanostructures: the case of silver. Chemistry-A European Journal, 11(2), pp.454-463.

Yin B, Ma H, Wang S and Chen S (2003) Electrochemical synthesis of silver nanoparticles under protection of poly $(\mathrm{N}-$ vinylpyrrolidone). J PhysChem B, 107: 8898-8904

Zhang L, Shen YH, Xie AJ, Li SK, Jin BK and Zhang QF (2006) One-step synthesis of monodisperse silver nanoparticles beneath vitamin E Langmuir monolayers. J Phys. Chem B, 110: 6615-6620.

\section{How to cite this article:}

Kavish Rajput, Sharad Raghuvanshi, Arun Bhatt, Sumit Kumar Rai, Pavan Kumar Agrawal. 2017. A Review on Synthesis Silver Nano-Particles. Int.J.Curr.Microbiol.App.Sci. 6(7): 1513-1528. doi: https://doi.org/10.20546/ijcmas.2017.607.182 